\title{
Entrepreneurship Development in a Local Context: Evidence from Entrepreneurs in the Eastern Region of Cameroon
}

\author{
Fouda Ongodo Maurice ${ }^{1} \&$ Pene Zongabiro Nina Pelagie ${ }^{2}$ \\ ${ }^{1}$ School of Economics and Management, University of Douala, Douala, Cameroon \\ ${ }^{2}$ School of Economics, Hebei University, Baoding, China. \\ Correspondence: Pene Zongabiro Nina Pelagie, School of Economics, Hebei University, 071002, Baoding, China.
}

Received: March 23, 2015

Accepted: April 8, 2015

Available online: April 15, 2015.

doi:10.11114/aef.v2i2.766

URL: http://dx.doi.org/10.11114/aef.v2i2.766

\begin{abstract}
:
In Cameroon, entrepreneurial activities are developed from two main cities namely; Douala and Yaoundé. Therefore researches on entrepreneurship development in Cameroon are based on entrepreneurs from these main cities, while other regions entrepreneurial activities are not considered as a target for entrepreneurship analysis. This paper analyses entrepreneurial activities in Eastern Cameroon that has a lowest level of enterprise creation that is in contrast to the abundant natural resources in the region. The study highlights the characteristic of local entrepreneurs and entrepreneurial activities as well as the local institutional environment context. The study was based on a survey of 138 local entrepreneurs and the study used both quantitative and qualitative approaches. The descriptive results revealed that local entrepreneurs are largely youthful and the entrepreneurial activities are mainly developed from the small business sector. The study found out that lack of infrastructure; government subsidies and financial resources negatively affected the development of entrepreneurship. The Study suggests that the development of activities from strategic sectors such as agro-industries, forestry industries and mining and a setting of suitable policies and developmental programs at a level of local government could contribute to the socio-economic development of the region and of the country at large.
\end{abstract}

Keywords: Cameroon, Entrepreneurship, entrepreneur, local institutional environment.

\section{Introduction}

The economic circumstances in the early 1980s led Cameroon into an economic crisis, mainly as a result of the fall of export income due to the price decrease of products such as coffee, cocoa, and oil in the international market. Following a rise of approximately $40 \%$ in the real effective exchange rate of the local currency, XAF Francs in 1994 and the increase of external debt and the budgetary deficit, prompted the government to withdraw from economic activities and a conductive environment was created that favored the emergence of the private sector (African Development Bank, 2007). The development of the private sector in Cameroon is perceived to be an alternative to youth unemployment that constitute a larger part of population according to National Statistics (2012) youth in the ranges of 15-34 years represent 34.3 per cent of 19406100 inhabitants in 2010. The private sector is focused on the development of business activities and industrial production in the agricultural, natural resources and mining sectors while government is concerned with the development of strategic sectors such as infrastructure, energy, and policies.

Today, in Cameroon, there are about 93,969 enterprises distributed across the country. Small-scale enterprises represent 75 per cent of the total number of enterprises in the country. However with the enterprise distribution remaining unbalanced and the majority of the enterprises located in Cameroon's big cities such as Yaoundé and Douala that accounted for 73.8 per cent of 93,969 enterprises that exist in the country (Cameroon General Enterprise Census, 2009). This unbalanced distribution of enterprises across the country has a negative impact on the entrepreneurship development in other parts of the country particularly in Eastern Cameroon that is mainly constituted by small cities and rural areas.

\section{Problem Statement}

Africa being a continent that has a large number of youths (7 to 10 million young people entering labor force each year (World Bank: Africa development indicators, 2011), Cameroon as well as other African countries are looking for means of providing jobs to these youths. In Cameroon entrepreneurial activities appeared to be an alternative to youth 
unemployment. Therefore, there is need to promote the development of entrepreneurial activities within the country. Since 1990, the Cameroonian government was forced to withdraw from the market due to the impact on the fall on farm produce (oil, cocoa, and coffee) on international market. Public companies that were mainly agro-industries were privatized. The major impact of the economic crisis was the increase in the number of jobless people, who developed a lot of survival economic activities to support themselves. This saw the emergence of the private sector nationwide. After the crisis the Cameroon government adopted many reforms to promote private investment. The adoption of investment code in 2002 stressed on the characteristics of investments and investors which also include some fiscal advantage to private investment according to given categories of the firms. Recent reforms including the creation of the enterprise registration center (one-stop shop) in 2010 to facilitate the official procedures of all licenses needed for entrepreneurs to acquire a legal statute. To improve dialogue between public actors and private actors', government created the Cameroon Business Forum in 2010. Government also created Small and Medium size Bank, National Agency of SMEs Promotion and Agricultural Bank in 2013 to support economic activities.

Despite government effort to promote the development of entrepreneurship, entrepreneurial activities are not yet widely developed within the country. Furthermore, entrepreneurial activities are mostly developed from the main cities (Yaoundé and Douala) while small cities and rural areas receive less attention regarding the development of entrepreneurial activities. Thus, this study aims to answer the following research questions: What are the characteristics of entrepreneurship in eastern Cameroon? How does the local environment influence the development of entrepreneurial activities in this region? What could be the effects of the development of entrepreneurial activities on the economic and social development of eastern Cameroon?

\section{Aim and Objectives of the Study}

The study aims at highlighting the development of entrepreneurial activities beyond big cities and stressing the influence of local institutional environment on the development of entrepreneurship in eastern Cameroon. Thus, the study pursues the following objectives: to analyze the characteristics of entrepreneurial actors; to stress the structures of entrepreneurial activities in eastern Cameroon; to highlight the impact of environmental conditions on the development of entrepreneurial activities and consequently the socio-economic development of entrepreneurs and the population of the eastern region of Cameroon at large. Therefore, this study stresses on the role of local institutional environment in the development of entrepreneurship. Environmental conditions including government policies and programs, regulatory framework, financial system (bank loans), can determine the size and the quality of entrepreneurial activities developed in the given country.

This paper is organized as follows: the next section presents the literature review on entrepreneurship and economic development as well as theoretical and empirical literature on entrepreneurship in Cameroon. Section 5 presents the methodology of the study. Results and interpretation are presented in section 6. Finally the discussion and conclusion of the study is presented at last.

\section{Literature Review}

\subsection{Theories on Entrepreneurial Orientations}

After a long time of studies into entrepreneurship, three main entrepreneurial orientations emerged from the literature on entrepreneurship including: the trait approach, the sociological approach and the economics approach.

The traits approach mainly from psychologist stresses on how some personal stimuli (individual personal characteristics such as personal beliefs and self-capability) influences individuals' perception towards entrepreneurship (McClelland, 1961 and Bandura, 1997). Indeed, individuals' personal traits such as age, gender, parents' job occupation could determine individuals' perception towards entrepreneurship. The Global Entrepreneurship Monitor (GEM) revealed that entrepreneurial activities are prevalent among those 25-35 years of age (Herrington \& Kelley, 2013). Gender also has an impact on the development of entrepreneurship and on the type of entrepreneurial activities developed. Women appear to be less interested in entrepreneurial activities than men do (Boissin, Chollet \& Emin, 2008). Parents' professional careers may also influence the choice of their children regarding entrepreneurship. Djankov, Qian, Roland and Zhuravskaya (2006) study on the entrepreneurship development in China and Russia found that entrepreneurs in China are much more likely to have close family members as entrepreneurs also, taking after them.

Sociologists on the other hand stress on how social norms and cultures influence the development of entrepreneurial activities; mostly the role of social groups (parents, friends, community etc) and how the belief system and values that prevail in a given society could favor or deter individuals' perception towards entrepreneurship (Shapero \& Sokol, 1982, and Hofstede, 1980).

Finally, the economists approach mainly focuses on the concepts of opportunities and institutions to analyze entrepreneurship phenomenon. Scholars from the opportunities approach focus on the role of the entrepreneurs as an opportunistic individual capable of detecting opportunities and to solve a problem of disequilibrium of the market 
system (Casson, 1982 and Kirzer, 1973). Thus an entrepreneur is perceived as an agent of economic development who takes advantage of opportunities and uses innovation to produce goods and services (Schumpeter, 1934). Institutional economists focus on the impact of environmental contexts on the development of entrepreneurship (North, 1990, Jackson, 2002, and Acemoglu, Johnson, Robinson \& Thaicharoen, 2003). For institutional analysts; political, economic and social structures explain the difference in the level of entrepreneurship development across countries. North (1990: 3) defined institutions as follows: "Institutions are the rules of the game in a society or more formally are the humanly devised constraints that shape human interaction". He argued that through the set of formal rules namely "rules of the game' and informal norms institutions reduce transactions cost and promote good macroeconomic environment.

Therefore, institutional aspects including government policies and programs, legal and judicial framework, financing system, technologies and social and cultural norms could enhance or hinder the development of entrepreneurial activities within a given country (Roxas, Lindsay, Ashill, \& Victorio, 2007).

\subsection{Entrepreneurship and Economic Development}

Defining entrepreneurship from an economics perspective, researchers consider an entrepreneur as someone who contributes to economic development through innovation and developmental entrepreneurial activities. Thus, many researchers (Stevenson \& Jarillo 1990, Schumpeter, 1934, and Drucker, 1985) support the view that the development of entrepreneurial activities contributes to economic development of countries. The important part of economic development of some countries such as USA, Japan and New Zealand and recently China one are attributed to the development of entrepreneurship as supported by Liu (2002), Chow (2004), and Li, Meng \& Zhang (2006) who argued that the private sector is a main component of Chinese economic growth.

Literature on entrepreneurship in Africa supports the fact that entrepreneurial activities would be an important pillar for African's economic development (Black \& Castaldo 2009, Daniels 1999, Kayanula \& Quartey 2000, and Herrington \& Kelley, 2013). But at the same time, some researchers recognize that entrepreneurship development in Africa is still facing some challenges. Herrington and Kelley (2013) asserted that most entrepreneurial activities are developed in the agricultural and mining sectors and the lack of a developed industry negatively affects the economic development of Africa. Kauffman (2005) argued that lack of financial resources constrain the emergency and future development of Small and Medium Enterprises in Africa. Alby, Auriol and Nguimkeu (2013) asserted that some social norms such as social networks have a negative impact on the economic outcome in Africa. Goudon and Kafando (2011) also agreed with other authors that African sub-Sahara region need a suitable strategy of industrialization to ensure its economic development.

However, some authors argue that Africa has the needed strength that could favor the development of entrepreneurial activities. Thus, April (2009) proposes that the diverse culture could be an advantage for creativity and innovation for young people in Namibia. And De Klerk and Havenga (2004) also argued that the building of institutional frameworks for entrepreneurship with the assistance from governments to develop networks and clusters could contribute to economic growth in Africa.

Entrepreneurship appears to play a key role in the economic development of a country where environmental conditions are set to support entrepreneurial acts. However, environmental conditions in Africa are still hindering the development of entrepreneurial activities of African entrepreneurs.

\subsection{The Development of Entrepreneurship in Cameroon}

The few literatures available on entrepreneurship in Cameroon are mainly focused on the challenges of entrepreneurship development.

Forge (2009), asserted that colonial period had a negative impact on entrepreneurship development in Cameroon but after the economic crisis in the early and mid-1980s entrepreneurial activities started to develop. Forge (2009) also proposes the entrepreneurship training at all levels of educational system as a factor to stimulate enterprise creation.

Financial resources appear to be main constraint to the development of entrepreneurial activities in Cameroon. Elle (2012) found out that microfinance did more of lending, savings and money transfers than provided micro insurance and training service to support entrepreneurs. This is in line with Warnier (1993) assertion that entrepreneurs who have access to bank loans or formal sources of financial resources are those at an advanced stage while entrepreneurs at an early stage mostly use informal sources to support their activities. Furthermore, Baland, Guirkinger, and Mali (2011) argued that some individuals borrow from credit cooperatives to constitute savings in the same institutions to avoid asking of assistance from relatives. While Pene (2014a) studying on the entrepreneurial activities of Cameroonian migrant workers in China discover that savings from abroad are major source of finance for small business activities back home.

Social norms and culture are important factors to the development of entrepreneurial activities in Cameroon. Fouda 
(2002) argued that a community mentality stronger among people of West Cameroon could be a motivating factor to entrepreneurship development in the Cameroonian context. And Pene's (2014b) study of small-scale producers of palm oil found out that entrepreneurial activities are mainly developed due to a social motive (the support of family).

The nature of economic activities revealed the characteristics of entrepreneurship development in Cameroon. General Enterprise Census conducted in 2009 revealed that the concentrations of activities in the tertiary sector at a level 86.5 per cent of the total enterprises from this sector were mainly developed in an informal manner. This explains the fact that 90 per cent of the workforce of 10 million people is working in the informal sector. And enterprises in which the majority of capital is held by nationals employed 68.1 per cent of the workforce while foreign owned firms only employed 15.6 per cent of this workforce. The General Enterprise Census also defined the profile of Cameroonian entrepreneurs. The survey revealed that the low level of education is a common characteristic among Cameroonian entrepreneurs, 44.2 per cent of total entrepreneurs have primary school education while age distribution revealed that 85.5 per cent of entrepreneurs are less than 50 years old and are mostly men.

It is in this vein that the improvement of business climate is needed to favor the development of entrepreneurial activities within the country. The Cameroon Business Climate survey in 2011 revealed that the adoption of rules and regulations suitable for small businesses and an action against corruption would promote enterprise creation.

The above literature review gives a general overview of entrepreneurship development in Cameroon. As noticed above this reality mainly concerned entrepreneurs from two main cities (Yaoundé and Douala), while entrepreneurs from other cities in general and entrepreneurs' activities from eastern Cameroon in particular are known or are less known. In order to suggest some recommendations that will improve the enterprise spirit observed in local context, this study analyze the characteristics of entrepreneurial actors, the types of entrepreneurial activities, the structure of local institutions and their contribution to the development of entrepreneurship in this region and economic development at large.

\section{Methodology of the Study}

\subsection{Methods and Population of the Study}

Bruton, Ahstrom, and Obloj (2008) asserted that there is a need to contextualize the research on entrepreneurship in emerging economies and developing economies and Roxas et al. (2007) propose a conceptual framework on the role of formal and informal institutional factors at the sub-national level such as city because a focus on institutional analysis at the national level only ignores the heterogeneity that exist within regions or cities of the given country. As noticed by Kamdem (2001) in the African context, research on entrepreneurship must be oriented more towards the understanding of its practices.

Therefore, this paper seeks to understand an entrepreneurship phenomenon through the analysis of social and economic context of entrepreneurs from eastern Cameroon (Shapero \& Sokol, 1982 and Kamdem, 2001). Thus this study follows institutional economist approach (North, 1990 and Roxas et al., 2007) to stress the role of local institutions in promoting the development of entrepreneurship in eastern Cameroon. Given an exploratory nature of the research, a survey was used as a research instrument. The study used both quantitative (descriptive statistics) and qualitative (phenomenology analysis) approaches.

The study focused on independent entrepreneurs as the target population because they are capable of giving more information and precise evaluation of local environmental conditions. The survey considered an entrepreneur as someone who owns and manages a business activity. The survey used simple random sampling method to choose respondents. Thus, the survey concerned every category of entrepreneurs: individual business, family business, ventures and firms. The survey included all four political-administrative zones (Lom \& Djerem, Kadey, Mbouba \& Ngoko and Haut-Nyong) of the East region. The survey included rural entrepreneurs and urban entrepreneurs from 14 cities and 7 villages and out of 200 questionnaires distributed, 138 were filled out by entrepreneurs. Entrepreneurs who took part in study were largely from the informal sector according to the nature of economic structure in the country. The study also focused on this sector to analyze the efficiency and the adaptability of government programs in promoting entrepreneurship at the local level.

\subsection{Data Collection and Data Analysis}

Questionnaires were used to collect the data from entrepreneurs. Questionnaires were administered to entrepreneurs face to face, using a paper support and it was in French, an official language spoken in this part of Cameroon. Data were collected from April 2014 to June 2014. The questionnaires were made up of 30 questions and constituted of variables such as follows: the demographic profile of the entrepreneurs, the characteristics of entrepreneurial activities, the motivations towards the activities and the impact of institutional environment on the development of activities. Method of data analysis is descriptive statistics including frequencies and percentages obtained from Statistical Package for Social Science (SPSS17) and served as tools for interpretation and phenomenology approach to analyze the characteristics of entrepreneurship that emerged from respondents' answers (Dana, 1995, and Labushagne, 2003). 


\section{Results and Interpretation}

\subsection{Socio-Bibliographic Profile}

Entrepreneurs' socio bibliographic profile included variables such as age, gender, marital status and parents' job occupation.

Table 1. Entrepreneurs' Profile

\begin{tabular}{llll}
\hline Variables & & Frequencies & Percentage \\
\hline Gender & Male & 65 & 47.1 \\
& Female & 73 & 52.9 \\
Age & Minimum & 18 & \\
& Maximum & 70 & \\
& Average & 35.01 & \\
Study Level & Primary level & 57 & 41.3 \\
& Secondary level & 71 & 51.4 \\
& Higher Education & 7 & 5.1 \\
& No education & 3 & 2.2 \\
& & & \\
Marital status & Married & 83 & 60.1 \\
& Single & 41 & 29.7 \\
& Widow & 11 & 8.0 \\
& Divorced & 02 & 1.4 \\
& In relationship & 01 & 0.7 \\
Parents' & Farmers & & 31.1 \\
Job occupation & Government employees & 13 & 9.4 \\
& Private sector workers & 10 & 7.2 \\
& Businessmen & 64 & 46.4 \\
& Others & 8 & 5.8 \\
& & &
\end{tabular}

\section{Source: Authors' survey}

Table 1 summarizes the entrepreneurs' profiles. The respondents that took part in this survey had an average age of 35 years. Gender distribution revealed that respondents that took part in this survey were largely women (at a level 52.9\%. of respondents). This large proportion of women is explained from the characteristic of activities that are mainly from informal sector. In Cameroon, women entrepreneurial activities are largely developed from informal sector generally these women lacks financial resources to develop activities from formal sector.

On the educational qualifications of the respondents, the survey found that 51.4 per cent had secondary education, 41.3 per cent had primary education while only 7 per cent had higher educational qualifications. This result could be explained from the large number of women in this sample as usually women from this part of Cameroon are less educated than men. Furthermore, the low level of educational background of entrepreneurs in this survey is in line with the General Enterprise Census that found out that 44.2 per cent of entrepreneurs that took part in national survey in 2009 have primary school education. In our survey the percentage is 41.3 per cent.

Marital status revealed that entrepreneurs are mostly married (60.1\% of 138 respondents are married). Despite the fact that marriage is one important value of culture in this region, the large percentage of married entrepreneurs could be also explained by the satisfaction of basic marriage needs (feeding, clothing, and schooling of children). Both husbands and wives have to contribute to the family income. Lastly parents' job occupation appears to have a certain influence on the choice to undertake entrepreneurial activities. The survey revealed that most entrepreneurs took after their parents at a level of 46.4 per cent while 31.1 per cent of the entrepreneurs' parents were farmers. The relative larger percentage of entrepreneurs among parents compared to other categories of job occupation (farmer, and government employee) showed how Parents' job occupation influence their children professional career choice (Djankov, Qian, Roland \& Zhuravskaya, 2006). 


\subsection{Characteristics of Entrepreneurial Activities}

Entrepreneurs' entrepreneurial activities included the nature of activities, the source of financial resources at the beginning and the legal existences of activities.

Table 2. Characteristics of Activities

\begin{tabular}{|c|c|c|c|}
\hline Variables & & Frequencies & Percentage (\%) \\
\hline \multirow[t]{7}{*}{ Nature of activity } & Agriculture & 12 & 8.7 \\
\hline & Livestock & 2 & 1.4 \\
\hline & Wood industries & 9 & 6.5 \\
\hline & Dressmaker & 1 & 0.7 \\
\hline & Small business & 64 & 46.4 \\
\hline & Services & 23 & 16.7 \\
\hline & Restaurants & 27 & 19.6 \\
\hline \multirow[t]{3}{*}{ Sector of economy } & Primary & 14 & 10.1 \\
\hline & Secondary & 10 & 7.2 \\
\hline & Tertiary & 114 & 82.7 \\
\hline \multirow{3}{*}{$\begin{array}{l}\text { Development of } \\
\text { activity }\end{array}$} & Stable & 34 & 24.60 \\
\hline & Increase & 83 & 60.1 \\
\hline & Decrease & 21 & 15.2 \\
\hline \multirow{2}{*}{$\begin{array}{l}\text { Financial resources } \\
\text { at the beginning: } \\
\text { personal savings }\end{array}$} & Yes & 124 & 89.9 \\
\hline & No & 14 & 10.1 \\
\hline \multirow{2}{*}{$\begin{array}{ll}\text { Legal } & \text { structures } \\
\text { register } & \end{array}$} & Yes & 58 & 42.0 \\
\hline & No & 80 & 58.0 \\
\hline
\end{tabular}

Source: Authors' survey

As shown in table 2, entrepreneurial activities are developed from the three economic sectors namely: primary, secondary and tertiary sectors. The results are similar to the national survey that found out that entrepreneurial activities are mainly from tertiary sector. In this survey, 82.7 per cent of activities are developed from this sector that is small businesses, services (pressing, hotels etc.), and restaurants. Small business activities have a relative larger proportion at a level of 46.4 per cent and mainly developed by women because small business activities immediately generate revenues that are used by these women to satisfy their large family needs.

The few industrial activities in this survey are largely from wood industries that transforms wood to semi or final product such as house furnishing. These findings calls upon the necessity to create high- technology industries specialized in the transformation of the wood that is widely distributed across the region.

Agriculture which is an important component of economic development of the region is less represented in this survey. This could be explained by the fact that the survey was carried out largely in the urban areas where jobless people are more willing to undertake small business activities than farming and livestock rearing which are abandoned to peasants in the rural areas. Efficient programs capable to stimulate the jobless to undertake agricultural activities that could be a pillar of economic development in the region are required.

On the evolution of activities, most entrepreneurs noticed the increase in the volume of their activities as 60.1 per cent of respondents noted that their activities have increased since the startup. These results showed that business opportunities are available in the region, so many developmental activities can emerged in the region hence the region is rich in natural resources which means available raw material for the development of industries.

At the beginning activities were largely financed from entrepreneurs' personal savings, 124 respondents out of 138 revealed that they used personal financial resources to support their activities. The used of personal savings constrain the development of activities and it explain the quality and the size of activities developed.

Concerning the legal existence of activities only 42 per cent of 138 entrepreneurs that took part in survey have registered their structures and they have obtained all the licenses and permits needed to exercise economic activities in Cameroon from the government's structures (institutions in charge of economic activities and local councils). These results show that activities are developed in the informal manner and the local government structures in charge of coordinating and regulating the informal sector are not effective on the ground.

The relationship between entrepreneurs and their employees is presented in table 3. 
Table 3. Relationship with Employees

\begin{tabular}{|c|c|c|c|}
\hline Variables & & Frequencies & Percentage $(\%)$ \\
\hline \multirow[t]{2}{*}{ Employee } & Yes & 107 & 77.53 \\
\hline & No & 31 & 22.47 \\
\hline \multirow[t]{2}{*}{ No Link with employee } & Yes & 20 & 18.69 \\
\hline & No & 87 & 81.31 \\
\hline \multirow{2}{*}{$\begin{array}{l}\text { Employee } \\
\text { wife/husband }\end{array}$} & Yes & 23 & 21.5 \\
\hline & No & 84 & 78.5 \\
\hline \multirow[t]{2}{*}{ Employee link: children } & Yes & 45 & 40.06 \\
\hline & No & 62 & 57.94 \\
\hline \multirow{2}{*}{$\begin{array}{l}\text { Employee link: Family } \\
\text { member }\end{array}$} & Yes & 35 & 32.71 \\
\hline & No & 72 & 67.29 \\
\hline \multirow[t]{2}{*}{ Employee link: Friends } & Yes & 29 & 27.10 \\
\hline & No & 78 & 72.90 \\
\hline
\end{tabular}

Source: Authors' survey

Table 3 showed that 107 entrepreneurs out of 138 are assisted by employees. The number of employee is between 1 to 122 according to the size of the structures or the activities developed. Employees are predominantly relatives. Only 20 Entrepreneurs out of 107 entrepreneurs affirmed that they do not have any link with their employees. These results showed the role of relative in the development of activities. So wives (husbands), children, family members and friends constituted the labor force.

\subsection{Entrepreneurial Orientation}

The survey revealed that reasons to undertake entrepreneurial activities are varied. Respondents' answers vary across different variables of entrepreneurial orientation such as: psychological orientation (to be independent), situational or sociological orientation (to survive, to create my own job), cultural orientation (to support my family), and economic orientation (to make profits). Table 4 summarizes the variables of entrepreneurial orientation.

Table 4. Entrepreneurial Orientation

\begin{tabular}{|c|c|c|c|c|}
\hline Variables & & & Frequencies & $\begin{array}{l}\text { Percentage } \\
(\%)\end{array}$ \\
\hline \multirow{2}{*}{$\begin{array}{l}\text { Psychological } \\
\text { orientation }\end{array}$} & \multirow{2}{*}{ To be independent } & Yes & 89 & 64.5 \\
\hline & & no & 49 & 35.5 \\
\hline \multirow{4}{*}{$\begin{array}{l}\text { Situational } \\
\text { orientation }\end{array}$} & \multirow[t]{2}{*}{ To survive } & yes & 92 & 66.7 \\
\hline & & no & 46 & 33.3 \\
\hline & \multirow{2}{*}{$\begin{array}{l}\text { To create my own } \\
\text { job }\end{array}$} & yes & 50 & 36.2 \\
\hline & & no & 88 & 63.8 \\
\hline \multirow{2}{*}{$\begin{array}{l}\text { Cultural } \\
\text { orientation }\end{array}$} & \multirow{2}{*}{$\begin{array}{l}\text { To support the } \\
\text { family }\end{array}$} & yes & 67 & 48.6 \\
\hline & & no & 71 & 51.4 \\
\hline \multirow{2}{*}{$\begin{array}{l}\text { Economic } \\
\text { orientation }\end{array}$} & \multirow[t]{2}{*}{ To make profit } & yes & 109 & 79.0 \\
\hline & & no & 29 & 21.0 \\
\hline
\end{tabular}

Source: Authors' survey

Table 4 showed that concerning psychological orientation (to be independent), a large score of yes at a level of 64.5 per cent is one of motivation that led to entrepreneurship among the respondents. This finding is similar to what other authors have found. They attribute the desire to satisfy personal goals as a reason to undertake entrepreneurial activity among some entrepreneurs (McClelland, 1961).

Situational orientation can be traced in the concept of necessity motive developed by Global Entrepreneurship Monitor. Entrepreneurs who pursue this orientation want to support themselves and create their own jobs that could give them an 
income needed to meet their needs (Herrington \& Kelley, 2013).

Cultural orientation is also one of the motives that promotes to entrepreneurship, but this motive is not as important as others. 51.4 per cent disagreed that supporting their family is part of the motive that drive their activities.

Economic orientation is the main motive that drives entrepreneurial activities among the respondents. 79 per cent affirmed that making the profits is the motive that pushed them to startup businesses. 'Making profits' can be linked to the opportunity motive mentioned by Global Entrepreneurship Monitor. This result is surprising when compared to some studies that found out that in developing economies, entrepreneurs are largely driven by the necessity motive than the opportunity motive (Herrington \& Kelley 2013, and Pene, 2014b).

\subsection{Entrepreneurs' Perception of the Local Institutional Environment}

Respondents' perceptions of the local business environment revealed that entrepreneurs' activities are influenced by the formal institutions.

Table 5. Local Institutional Environment

\begin{tabular}{|c|c|c|c|c|}
\hline Variables & & & Frequencies & $\begin{array}{l}\text { Percentage } \\
(\%)\end{array}$ \\
\hline \multirow{12}{*}{$\begin{array}{l}\text { Formal } \\
\text { environment }\end{array}$} & \multirow{2}{*}{$\begin{array}{l}\text { Administrative } \\
\text { procedures }\end{array}$} & Yes & 44 & 31.9 \\
\hline & & no & 94 & 68.1 \\
\hline & \multirow{2}{*}{$\begin{array}{l}\text { Government } \\
\text { subsidies }\end{array}$} & yes & 75 & 54.3 \\
\hline & & no & 63 & 45.7 \\
\hline & \multirow[t]{2}{*}{ Infrastructures } & yes & 71 & 51.4 \\
\hline & & no & 67 & 48.6 \\
\hline & \multirow[t]{2}{*}{ Financial resources } & yes & 80 & 58.0 \\
\hline & & no & 58 & 42.0 \\
\hline & \multirow[t]{2}{*}{ Technology } & yes & 40 & 29.0 \\
\hline & & No & 98 & 71.0 \\
\hline & \multirow[t]{2}{*}{ Labor force } & Yes & 28 & 20.3 \\
\hline & & No & 110 & 79.7 \\
\hline Informal & \multirow[t]{2}{*}{ Corruption } & Yes & 36 & 26.1 \\
\hline Environment & & No & 102 & 73.9 \\
\hline
\end{tabular}

Source: Authors' survey

Table 5 showed the variables of local institutional environment. Entrepreneurs were asked to agree or not if variables such as, administrative procedures, government subsidies, infrastructures, financial resources, technology, labor force and corruption do negatively influence entrepreneurial activities in the region. The lack of government subsidies (54.3\% of respondents), the infrastructures (transportation system, water and electricity) at a level of 51.4 per cent of respondents and financial resources $(58 \%)$ are the main factors that negatively impacts the development of entrepreneurship among the respondents.

Concerning administrative procedures only 31.9 per cent of the 138 respondents perceived it as a constraint. This rate is lower than the national one mentioned in Cameroon General Enterprise Census, (2009) that found out that administrative procedure was fourth impediment at a level of 37.6 per cent of entrepreneurs' opinions. These results showed that government effectiveness is more efficient at the local level compared to the national one.

Impacts of labor force, technology and corruption as constraints to the development of entrepreneurship are insignificant. In this study, on the area of corruption the result is surprising as compared to the results of national census where entrepreneurs mentioned corruption as a second impediment to the development of entrepreneurship at a level of 50.6 per cent of entrepreneurs opinions, in this study, only 26.1 per cent out of 138 respondents agreed that corruption negatively impact on the development of entrepreneurship in the region. These results revealed the relative efficiency of local government in the fight of corruption compared to the central government.

\section{Discussion}

The above results presented the development of entrepreneurship in the eastern region of Cameroon. The analysis stresses on the local entrepreneurs profile, the characteristic of their activities and entrepreneurs' perception of the local 
institutional environment. This section focuses on analysis of the survey findings and provides some recommendations to improve the development of entrepreneurial spirit observed among the local entrepreneurs.

\subsection{Entrepreneurial activities in East- Cameroon}

\subsubsection{The Nature of Entrepreneurial Activities}

As shown earlier in the results, entrepreneurial activities are developed by entrepreneurs at the average age of 35 years most of them are married and have a secondary level of education. These entrepreneurs are largely young.

As noticed earlier, youth unemployment is a challenge for the Cameroonian government. Despite the set of developmental programs to reduce the rate of unemployment such as: the creation of the ministry in charge of youth affairs and entrepreneurship promotion programs (national program for informal actors, national program of rural and urban youth) that provide some financial and technical assistance to support youth entrepreneurial projects. These programs remain inadequate and insufficient as none of the respondents from this study have received any assistance from these structures. There is need for government to review its strategies of entrepreneurship promotion so that they can developed from the local government (communal councils) that well perceive the opportunity and the strategies adapted to local communities. Concerning entrepreneurial activities, the dominance of tertiary sector largely from businesses, this reflects the economic structure of the country where the services (tertiary sector) occupied the largest part and contributed 47.8 per cent in 2013 to the country's GDP (African Economic Outlook, 2014). Eastern Cameroon has a land that could be used for agricultural activities hence the creation of agro industry firms that could provide permanent jobs to local people and contribute to poverty reduction is required.

The region also has a big forest, but most forestry industries are focused on the production of wood with most products being for export. In this study, only few wood industries focusing on the production of house furnishing were found among local entrepreneurs. The mining sector that could also be exploited by local entrepreneurs is regrettably developed by foreign companies. Local entrepreneurs need to be engaged in this sector that creates more value and jobs opportunities. As revealed in the General Enterprise Census (2009), the Eastern Region has a lowest number of industries at $0.7 \%$ ( 82 industries) out of 11685 industries that exist in the country in 2009. There is need to process the transformation of natural resources into final or semi-final products. This sustainable economic development required the development of industries.

\subsubsection{Entrepreneurs' Entrepreneurial Orientation}

Concerning entrepreneurial orientation, the study has shown that entrepreneurs from this part are mainly driven by the profit motive. While the entrepreneurs' links with employees appear that entrepreneurial activities are still developed with the purpose of providing jobs to actors themselves and to their relatives, family members (wife/husband, children and member of same community) and friends offer a labor force that is generally cheaper to the labor market one. Thus Labor force expenditures are reduced and the business net profit increases. Generally in entrepreneurship literature, supporting family or social networks is perceived as an obstacle to entrepreneurship development in the African context (Alby et al., 2013 and Baland et al., 2011). The perception of social networks or support family motive in this perspective is true when compared to the opportunity motive that drive entrepreneurial activities in developed economies and it appear to be a best motive to entrepreneurship development (Schumpeter, 1934, and Drucker, 1985).

However and as noticed by De Klerk and Havenga (2004) the suitable institutional framework to develop networks and clusters could have a positive impact on entrepreneurship. This is also in line with Bruton et al. (2008) research which proposes that entrepreneurship should be contextualized for emerging economies. This research concurs with Bruton et al. (2008) that entrepreneurial reality is different from one region to another. The motivational factors that are perceived as successful such as opportunity driven motive factor for developed economies (Central Europe and North America) should not be considered as the driving motives factor in developing economies in general and in Africa in particular where community mentality prevails. Community mentality is perceived as a negative factor due to a lack of suitable framework in which it is applying. Furthermore, the environmental change has also altered the original sense of community mentality that consisted to the joining effort of each family member to achieve the family success. Transposed to the enterprise framework; a single family member constitutes in themselves a resource (technical, labor, finance) for entrepreneurship development.

\subsection{Local institutions and the development of Entrepreneurship}

Various literatures (North, 1990, and Baum \& Oliver, 1992) recognize the influence of institutions on economic development and on entrepreneurship as well. Institutions (formal or informal) provide incentives as well as constraints to entrepreneurship development (North, 1990). Entrepreneurs in this study are facing some challenges related to their contextual environment (Jackson, 2002). The survey revealed some variables of formal institutions such as government policies: basic infrastructures, administrative procedures, financial resources that impact negatively on the development of entrepreneurship. 
During the survey, entrepreneurs largely lamented that the development of basic infrastructures such as road and transportation system that are government (central and local) responsibilities are lacking. Transportation cost or distribution cost of products are constraints faced by entrepreneurs in their daily activities. The eastern region of Cameroon is spacious, but lacks good road infrastructure to link main cities and the region to other regions and even to neighboring countries (Central Republic of Africa and Republic of Congo) where entrepreneurs could supply their products. The weak coverage of the region in terms of electricity and water supplies constitute another challenge for industrial firms and limited the establishment of industries in the regions.

Concerning legal framework (administrative procedures); the official procedures (required procedures for an enterprise creation: the deadline to accomplish a procedure, the cost of the procedure institutionalization sets the payment of minimum capital during the registration) appear to be long, complex, and costly at the national level while the local government structures appear to improve on these procedures. Despite this improvement, activities are still developed from an informal sector. To be more efficient, policies and programs to reduce the dominance of informal sector should be developed at the local government level.

On financial support, results revealed that entrepreneurs used informal means to support their activities with family financial assistance or owner's personal savings being the major sources of seed money. Most of respondents lamented that is difficult to obtain loans from banks because they lacked collateral besides the bank loans procedures being cumbersome. Thus, entrepreneurs opt for their personal savings or some microfinance institutions. But as noticed earlier by Elle (2012) microfinance institutions in Cameroon are mostly focused on microloans, savings and money transfer that are insufficient to support entrepreneurial activities. A suitable financial system could help entrepreneurs to participate in capital accumulation and develop a capital market.

Corruption is generally a barrier to the socio-economic development and the development of entrepreneurial activity in particular. As revealed by the findings of Business Climate Survey (2011) and General Enterprise Census (2009), corruption remains rampant throughout the territory and for all size of enterprises and in all sectors as well. However, entrepreneurs who took part in this study affirmed that acts of corruption have an insignificant impact on their activities development. Policies and strategies to reduce corruption appear to be more efficient at a local level. As noticed by Forge (2009), the Cameroonian government needs to educate its agents and all officers on the ills of corruption in order to facilitate entrepreneurship promotions.

\section{Conclusion}

This paper has presented the context of entrepreneurship development in eastern Cameroon- a region that has a lowest rate of enterprise creation, despite the fact that the region is the richest in natural resources and in land distribution. The motivation of the study was to highlight the role of local environment conditions on the development of entrepreneurships in a given region of the country.

The study found out that entrepreneurial activities in the eastern region of Cameroon are developed by entrepreneurs who have the same profile as the one attributed to common Cameroonian entrepreneurs who have an average age below 50 years. Entrepreneurial activities are mainly small businesses with the majority being in the service industry. Entrepreneurial orientation is primarily driven by profits and survival motives. Relatives constitute a main source of labor force and financial support. The analysis has shown that local entrepreneurs' activities are not developed based on local resources (land, forestry and mining).

This paper asserts that, entrepreneurs have to develop activities from the sector as per available resources. This development of agro-industries and forestry product industries transform wood into semi and final products. Government's action to facilitate local entrepreneurs to obtain mining licenses to control this sector that is in the hands of foreigners is required. Agro-industries, forestry industries and mining industries are main sectors hence if well-developed they would create permanent jobs and improve the living conditions of local populations as well as the socio-economic development of the eastern region.

Institutional environment in this study presented some constraints that face local entrepreneurs; the action is required from government to develop infrastructure such as road, electricity and water supply and the transportation system. The defining and the planning of policies and the developmental programs at a local government level (councils) should be more efficient in their implementation on the ground. The enforcement mechanisms and contracts at local level are the basic conditions needed in the framework of entrepreneurship development and the economic development of the region and the country as well.

\section{Acknowledgements}

The authors want to thank Mr. Gbowe Gbowe Simplice who assisted them to collect data. They also thank all entrepreneurs that filled out the questionnaires. 


\section{References}

Alby, P., Auriol, E., \& Nguimkeu, P. (2013). Social barriers to entrepreneurship in Africa: the forced mutual help hypothesis. Retrieved from http://www.cmi.no/file/?2371.

Acemoglu, D., Johnson, S., Robinson, J. \& Thaicharoen Y. (2003). Institutional cause macroeconomic symptoms: Volatility, crises and growth. Journal of monetary economies, 50(1), 49-123. http://dx.doi.org/10.1016/S0304-3932(02)00208-8

African Bank Development. (2007). Cameroon Structural Adjustment Program III (PASIII). http://www.afdb.org/fileadmin/uploads/afbd/Document/EvaluationReports/19614240-FR-CAMEROON-PAS-III.P DF. Accessed on February 4, 2014.

African Economic Outlook. (2014). Cameroon, 2014 available on

http://www.africaneconomicoutlook.org/fileadmin/uploads/aeo/2014/PDF/CN_Long_EN/Cameroun_EN.pdf. Accessed on March 22, 2015

April, W. I. (2009). Foresting entrepreneurship in developing nations: tapping into the hidden potential of Namibia rural youth. Journal of Asia Entrepreneurship and Sustainability, 5(1), 78-105.

Baland, J. M., Guirkinger, C., \& Mali, C. (2011). Pretending to be poor: Borrowing to escape forced solidarity in Cameroon. Economic developmental and cultural change, 60(1), 1-16. http://dx.doi.org/10.1086/661220

Bandura, A. (1997). The exercise of control Self-efficacy. MacMillan.

Baum, J. A., \& Oliver .C. (1992). Institutional Embedness and the dynamics of Organizational populations. American Sociological Review, 57(4), 540-559. http://dx.doi.org/10.2307/2096100

Black, R., \& Castaldo, A. (2009). Return migration and entrepreneurship in Ghana and Cote d'Ivoire: The role of capital transfers. Tjjdschriff voor economishe en sociale geografie , 100(1), 44-58. http://dx.doi.org/10.1111/j.1467-9663.2009.00504.x

Boissin, J. P., Chollet, B., \& Emin, S. (2008). Les croyances des étudiants envers la création d'entreprise.(Students beliefs towards enterprise creation). Revue Française de Gestion, 11, 25-43. http://dx.doi.org/ 10.3166/rfg.180.25-43

Bruton, G. D., Ahstrom, D., \& Obloj, K. (2008). Entrepreneurship in emerging economics where are we today and where should the research go in the future. Entrepreneurship Theory and Pratrice, 32(1), 1-14. http://dx.doi.org/10.1111/j.1540-6520.2007.00213.x

Casson, M. (1982). The Entrepreneur: An Economic Theory. Oxford: Martin Robertson.

Chow, G. (2004). Economic reform and growth in China. Annals of Economics and Finance, 5, 93-118.

Dana, L. P. (1995). Entrepreneurship in remote sub-Arctic community. Entrepreneurship Theory and Practice, 20, 57-72.

Daniels, L. (1999). The role of small enterprises in the household and national economy in Kenya: a significant contribution or a last resort. World Development, 27(1), 55-65. http://dx.doi.org/10.1016/S0305-750X (98)00120-X

De Clercq, D., Danis, W. M., \& Dakhili, M. (2010). The moderating effect of institutional context on the relationship between associational activity and new business activity in emerging economies. International Business Review, 19, 85-101. http://dx.doi.org/10.1016/i.ibuserev.2009.09.002

Djankov, S., Qian, Y., Roland, G., \& Zhuravskaya, E. (2006). Entrepreneurship in development: First Results from China and Russia. Paper presented at the AmericanEconomic Association Conference. Boston.

Drucker, P. (1985). Les Entrepreneurs (The entrepreneurs). Editions Tendances Actuelles: L'Expansion Hachette, Jean Claude Lattes.

Elle, S. (2012). Microfinance and entrepreneurship in Cameroon. Journal of Asia Entrepreneurship and Sustainability, $8(1), 121-159$.

Forge, L. (2009). Historical development of Entrepreneurship in Cameroon economy from 1960-2007. Journal of Asia Entrepreneurship and Sustainability, 5(3), 1-16.

Fouda, O. M. (2002). La perception de l'esprit d'entreprise chez les jeunes des différentsgroupes ethniques camerounais (The perception of entrepreneurship among young people from different ethnic group in Cameroon),. Actes Deuxième congrès de l'entrepreneuriat, champ de l'entrepreneuriat et dynamique des sociétés. Bordeaux.

Goudon, M., \& Kafando, C. (2011). Caractéristiques structurelles et industrialisation enAfrique : une première 
exploration (Industrialization and Structural characteristics in Africa: An initial exploration). Working paper retrieved from http://ideas.repec.org/p/hal/wpaper/halshs-00659824.htm\#download.

Herrington. M., \& Kelley. D. (2013). Global Entrepreneurship monitor. Sub-Saharan Africa regional Report. Retrieved from http://www.gemconsortium.org/docs/2009/gem-2012-sub-saharan-africa-regional-report .

Hofstede, G. H. (1980). Culture's consequences: International differences in work-related values. Newbury Park, CA Sage.

Jackson, P. (2002). Business Development in Asia and Africa: The Role of Government agencies. Hampshire, Palgrave.

Kamdem, E. (2001). Entrepreneuriat et sciences sociales en Afrique. (Entrepreneurship and social sciences in Africa). International Management, 6(1), 17-31.

Kauffman.C. (2005). SMEs financing in Africa. OECD development centre:Policy Insights. http://www.oecd.org/dev/34908457.pdf. Accessed on February 2, 2014.

Kayanula, D., \& Quartey, P. (2000). The policy environment for promoting small medium-sized enterprises in Ghana and Malawi. IDPM Finance and Development Research Programme, Working Paper Series, 15.

Kirzer, I. (1973). Competition and Entrepreneurship. Chicago: University of Chicago Press.

Labuschagne, A. (2003). Qualitative research-Airy fairy or fundamental. The Qualitative Report, 8(1), 100-103.

Li, H., Meng, L., \& Zhang, J. (2006). Why do entrepreneurs enter politics: Evidence from China. Economic Inquiry, 44(3), 559-578. http://dx.doi.org/10.1093/ei/cbj031

Liu, Y. (2002). Development of private entrepreneurship in China: Process, Problems and Countermeasures. Chinese Academy of Social Sciences (CASS). Working Paper. http://www.mansfieldfdn.org/backup/programs/program_pdfs/ent_china.pdf.

Mc Clelland, D. C. (1961). The achieving society. London: The Free Press.

North, D. (1990). Institutions, Institutional Change and Economic Performance. Cambridge: Cambridge University Press.

Pene, Z. N. P. (2014a). Entrepreneurial activities among African migrants: evidence from Cameroonian migrants' workers in China. Asian Academy Journal of Social Sciences and Humanities, 1(25), 38-54.

Pene, Z. N. P (2014b). The contribution of palm grove to the Cameroonian rural economic Development. Research in World Economy, 5(2), 159-168. http://dx.doi.org/10.5430/rwe.v5n2p159.

Republic of Cameroon. (2012). Deuxieme Enquete sur L'Emploi et le Secteur Informel au Cameroun (second national census of Labor and unemployment). Yaounde: National Institute of Statistics Retrieved from http://www. Statistics- cameroon.org.

Republic of Cameroon. (2009). General Enterprise Census. Retrieved from National Institute of Statistics on http://www. Statistics- cameroon.org.

Roxas, H. B., Lindsay, V., Ashill, N., \& Victorio, A. (2007). An institutional view of local entrepreneurial climate. Journal of Asia Entrepreneurship and Sustainability, 3(1), 1-28.

Shapero, A., \& Sokol, L. (1982). The social dimension of entrepreneurship. Kent C.ASexton D. L \& Vesper .

Schumpeter, J. A. (1934). The Theory of Economic Development: Harvard Economic Studies. Cambridge: Havard University.

Stevenson, H. H., \& Jarillo, J. C. (1990). A paradigm of entrepreneurship:Entrepreneurial Management. Strategic Management Journal, 11(5), 17-27.

Warnier, J. (1993). L'esprit d'entreprise au Cameroun (enterprise spirit in Cameroon). Paris: Karthala.

World Bank. (2011). Africa Development Indicators. Washington D.C: World Bank. http://data.worldbank.org/sites/default/files/adi_2011-web.pdf.

\section{(c) EY}

This work is licensed under a Creative Commons Attribution 3.0 License. 